\title{
The Role of the Hypothalamic Paraventricular Nucleus and the Organum Vasculosum Lateral Terminalis in the Control of Sodium Appetite in Male Rats
}

\author{
Laura A. Grafe, ${ }^{1}$ Anne E. Takacs, ${ }^{2}$ Daniel K. Yee, ${ }^{3}$ and Loretta M. Flanagan-Cato ${ }^{1,2,4}$ \\ ${ }^{1}$ Neuroscience Graduate Group, Departments of ${ }^{2}$ Psychology and ${ }^{3}$ Animal Biology, and the ${ }^{4}$ Mahoney Institute of Neurological Sciences, University of \\ Pennsylvania, Philadelphia Pennsylvania 19104
}

\begin{abstract}
Angiotensin II (AngII) and aldosterone cooperate centrally to produce a robust sodium appetite. The intracellular signaling and circuitry that underlie this interaction remain unspecified. Male rats pretreated with both deoxycorticosterone (DOC; a synthetic precursor of aldosterone) and central AngII exhibited a marked sodium intake, as classically described. Disruption of inositol trisphosphate signaling, but not extracellular-regulated receptor kinase 1 and 2 signaling, prevented the cooperativity of DOC and AngII on sodium intake. The pattern of expression of the immediate early gene product cFos was used to identify key brain regions that may underlie this behavior. In the paraventricular nuclei (PVN) of the hypothalamus, DOC pretreatment diminished both AngII-induced cFos induction and neurosecretion of oxytocin, a peptide expressed in the PVN. Conversely, in the organum vasculosum lateral terminalis (OVLT), DOC pretreatment augmented cFos expression. Immunohistochemistry identified a substantial presence of oxytocin fibers in the OVLT. In addition, when action potentials in the PVN were inhibited with intraparenchymal lidocaine, AngII-induced sodium ingestion was exaggerated. Intriguingly, this treatment also increased the number of neurons in the OVLT expressing AngII-induced cFos. Collectively, these results suggest that the behavioral cooperativity between DOC and AngII involves the alleviation of an inhibitory oxytocin signal, possibly relayed directly from the PVN to the OVLT.
\end{abstract}

Key words: aldosterone; angiotensin; oxytocin; receptor signaling; sodium appetite

\section{Introduction}

The hormones angiotensin (AngII) and aldosterone are key defenders of electrolyte balance, blood volume, and blood pressure (Peach, 1977). In the event of sodium depletion, hypovolemia, and/or hypotension, AngII and aldosterone are produced, which engage homeostatic responses, including a prodigious drive for sodium consumption (Ganong, 1977). Exogenous administration of either hormone alone produces a modest sodium intake; however, combined treatments result in markedly greater sodium consumption (Fluharty and Epstein, 1983), suggesting cooperative neural mechanisms. Steady progress has been made in revealing the independent natriorexic effects of AngII and aldosterone; however, the mechanism for the cooperative actions of

\footnotetext{
Received Sept. 17, 2013; revised May 16, 2014; accepted June 5, 2014.

Author contributions: L.A.G., D.K.Y., and L.M.F.-C. designed research; L.A.G. and A.E.T. performed research; L.A.G. analyzed data; L.A.G. and L.M.F.-C. wrote the paper.

This work was supported by the NIH Grants R01 HL091314. Preliminary results were reported at the Society for Neuroscience meeting (New Orleans, LA, 2012) and the Society for Behavioral Neuroendocrinology (Madison, WI, 2012). We thank the dedicated assistance of Daris Olaleye, the expertise of Drs Joseph Verbalis and Qin Xu at Georgetown University in conducting radioimmunoassays for oxytocin, and Drs Edward Stricker and Irwin Lucki for insightful discussions about these experiments.

The authors declare no competing financial interests.

Correspondence should be addressed to Dr Laura A. Grafe, Neuroscience Graduate Group, University of Pennsylvania, 3720 Walnut Street, Philadelphia, PA. E-mail: laurafel@mail.med.upenn.edu.

DOI:10.1523/JNEUROSCI.3979-13.2014

Copyright $\odot 2014$ the authors $\quad 0270-6474 / 14 / 349249-12 \$ 15.00 / 0$
}

AngII and aldosterone to promote a greater than additive effect on sodium ingestion remains unclear.

An intriguing model has been proposed to explain the synergistic actions of AngII and aldosterone on sodium ingestion based on disinhibition (Stricker and Verbalis, 1987; Blackburn et al., 1992a). In particular, central AngII activates oxytocin neurons in the paraventricular nuclei (PVN) and supraoptic nuclei (SON; Akaishi et al., 1980). Given that centrally released oxytocin suppresses sodium ingestion, AngII would be expected to elicit limited salt intake. Pretreatment with a mineralocorticoid diminishes AngII-induced oxytocin neuronal activation (Stricker and Verbalis, 1996, 2004; Roesch et al., 2001), thereby disinhibiting natriorexia. The exact role of oxytocin in the aldosterone-AngII interaction on sodium appetite remains unclear (Blackburn et al., 1992a; Fitts et al., 2003; Rigatto et al., 2003). In particular, the brain region in which oxytocin acts to inhibit sodium appetite is unknown.

A variety of studies have provided insight into the behavioral and endocrine effects of AngII. Circulating AngII binds to AngII type 1 receptors (AT1R) in the subfornical organ (SFO) and organum vasculosum lateral terminalis (OVLT), brain regions with an incomplete blood-brain barrier (Ganong, 1984). The SFO and OVLT relay information to the PVN and SON (Miselis, 1981; McKinley et al., 1992b) to prompt secretion of arginine vasopres$\sin$ (AVP) and oxytocin (Bisset et al., 1971). The AT1R is a heptahelical receptor that triggers inositol 1,4,5-triphosphate (IP3) 
production and $\mathrm{Ca}^{2+}$ mobilization (Smith et al., 1984; Enjalbert et al., 1986; Taylor et al., 1990; Beresford and Fitzsimons, 1992). In parallel, mitogen-activated protein kinase kinase (MEK) becomes phosphorylated, which activates the p42 and p44 isoforms of mitogen-activated protein kinase, also referred to as extracellular signal-regulated kinase 1 and 2 (ERK1/2; Sadoshima et al., 1995). IP3 signaling mediates AngII-induced thirst, whereas the ERK1/2 signaling pathway mediates sodium appetite (Daniels et al., 2005, 2009; Felgendreger et al., 2013). It is unclear whether these AngII-induced signal transduction pathways are affected by mineralocorticoids in brain targets.

To investigate the model of Aldo-AngII-oxytocin control of sodium appetite, we took a multidisciplinary approach investigating signal transduction, functional neuroanatomy, and reversible lesions. Initial results were inconsistent with the view that mineralocorticoids simply amplify the signaling effects of AngII. Subsequent findings implicated an inhibitory oxytocinergic link between the PVN and the OVLT. Together, these results confirm and extend the working model that the aldosterone-AngII cooperative effect on sodium appetite involves hypothalamic disinhibition.

\section{Materials and Methods}

Animals. Adult male Sprague-Dawley rats $(n=68)$ that weighed between 225 and $250 \mathrm{~g}$ were obtained from Charles River Laboratories. Rats were housed in groups of two in plastic tubs with standard bedding and with food and water available ad libitum, except during experimental procedures. The temperature in the colony was maintained at $22^{\circ} \mathrm{C}$ with a $12 \mathrm{~h}$ reversed light/dark cycle. Animals were allowed at least 1 week to acclimate to the colony before any procedures were performed. The Institutional Animal Care and Use Committee of the University of Pennsylvania approved all procedures with animals.

Drugs. Deoxycorticosterone acetate (DOC; Sigma-Aldrich) was administered subcutaneously (s.c.) at a dose of $0.25 \mathrm{mg}$ in $0.2 \mathrm{ml}$ of sesame oil (Sigma-Aldrich). DOC is typically used instead of aldosterone because it penetrates the blood brain barrier more easily than aldosterone because of its low capacity for hydrogen bond formation (Geerling and Loewy, 2009). Sesame oil was administered at $0.2 \mathrm{ml}$ subcutaneously as a control. The specific doses for each drug given intracerebroventricularly were as follows: 2.0 or $20.0 \mathrm{ng}$ AngII in a volume of $2.0 \mu \mathrm{l}$ (Bachem), 2.0 $\mathrm{nmol}$ U0126 dissolved in 10\% DMSO in a volume of $2.0 \mu \mathrm{l}$ (Promega), $20.0 \mathrm{ng}$ xestospongin- $\mathrm{C}(\mathrm{XC})$ dissolved in $2 \% \mathrm{DMSO}$ in a volume of 2.0 $\mu \mathrm{l}$ (Tocris Bioscience), $8.5 \mathrm{nmol} /$ side of $2 \%$ lidocaine in a volume of 0.4 $\mu \mathrm{l}$ (Phoenix Pharmaceuticals), $10.0 \mu \mathrm{g}$ oxytocin in a volume of $1 \mu \mathrm{l}$ (Bachem; catalog \# H-2510). Artificial CSF (aCSF; R\&D Systems) plus $10 \%$ DMSO was administered intracerebroventricularly as a vehicle control in a volume of $2.0 \mu \mathrm{l}$.

Surgeries. Surgeries were performed in aseptic conditions. Animals were anesthetized with isofluorane gas before being fixed in a stereotaxic frame and implanted with a 26 gauge guide cannulae (Plastics One) aimed at the lateral ventricle. For the lateral ventricle surgeries, coordinates were as follows: $0.48 \mathrm{~mm}$ caudal to bregma, $1.6 \mathrm{~mm}$ from mid-line and $4.2 \mathrm{~mm}$ ventral to dura mater. For the lidocaine experiments, an additional 26 gauge double-guide cannula $(0.8 \mathrm{~mm}$ apart $)$ was implanted into the PVN. For PVN double cannulae, coordinates were as follows: 1.8 $\mathrm{mm}$ caudal to bregma, $0.4 \mathrm{~mm}$ from the mid-line, and $7.7 \mathrm{~mm}$ ventral to dura mater. These coordinates were chosen to allow an internal injection cannula to extend beyond the guide cannula into either the ventricular space or the PVN itself. The cannulae were fixed in place with dental cement and bone screws, and the animals were allowed at least $5 \mathrm{~d}$ to recover before verification procedures were performed. After surgery, animals were injected with yohimbine $(0.11 \mathrm{mg} / \mathrm{kg}$, Ben Venue Laboratories). Upon awakening, animals were singly housed.

Five days after surgery and before undergoing experimental treatments, animals were tested for correct lateral ventricle cannula placement and patency. They were given an intracerebroventricular injection of $20.0 \mathrm{ng}$ of AngII diluted in aCSF via a Hamilton syringe connected with PE-10 tubing to an injector that terminated $1 \mathrm{~mm}$ beyond the guide cannula. Animals were excluded from the experiment if they failed to demonstrate a drinking response in $<30 \mathrm{~s}$ consuming at least $3 \mathrm{ml}$ of water in two separate AngII challenges. Animals began behavioral testing $3 \mathrm{~d}$ after the intracerebroventricular test injections.

Behavioral studies. Rats were placed in individual wire mesh-bottomed cages with water and food available ad libitum. One day before injections, rats acclimated for $1 \mathrm{~h}$ to two $25 \mathrm{ml}$ bottles containing tap water and $1.5 \%$ saline, each marked with $0.2 \mathrm{ml}$ graduations. Vehicle or DOC $(0.25 \mathrm{mg})$ was administered to each rat in $0.2 \mathrm{ml}$ of sesame oil twice daily $(10 \mathrm{~h}$ apart) for $3 \mathrm{~d}$.

To investigate the role of ERK1/2 in this model of water and sodium consumption, rats were assigned to specific intracerebroventricularly conditions on the fourth day: vehicle, U0126, AngII, or U0126 plus AngII. U0126 was administered 15 min before AngII in the last condition (Daniels et al., 2009; Felgendreger et al., 2013). To examine the role of the OVLT activation in the potentiation of sodium appetite, rats were assigned to specific intracerebroventricular conditions on the fourth day: vehicle, XC, AngII, or XC plus AngII. XC was administered 20 min before AngII in the last condition (Brennan et al., 2008; Li et al., 2011). To evaluate the role of the PVN in DOC and AngII-induced sodium appetite, rats were administered either vehicle or lidocaine directly into the PVN over the course of $1 \mathrm{~min}$, followed 5 min later by injection of vehicle or AngII intracerebroventricularly (Flanagan et al., 1992; Fernandes et al., 2007). The bilateral lidocaine injection was performed using a dual infusion pump (Harvard Apparatus). In an additional study examining the role of oxytocin in sodium appetite, oxytocin or vehicle was administered intracerebroventricularly $15 \mathrm{~min}$ before injections of lidocaine and AngII (Blackburn et al., 1992b).

For all behavioral experiments, after the last drug treatment was given, rats were returned to their cages, and water and saline levels were measured at 15 min intervals for the first hour and then at 30 min intervals for the next hour. Food was not available during behavioral testing.

Western blot. Animals were pretreated twice daily for $3 \mathrm{~d}$ (10 h apart) with vehicle or DOC, as described above. On day 4, rats were administered either vehicle, 2 ng AngII, or 20 ng AngII intracerebroventricularly. Two minutes after the last injections, animals were rapidly decapitated and brains were flash frozen in hexane over dry ice. Using a cryostat, 1 $\mathrm{mm}$ punches of brain regions of interest (OVLT, SFO, PVN, SON) were collected from $300 \mu \mathrm{m}$ slices. The OVLT and SFO were combined and the PVN and SON punches were combined from each rat to ensure sufficient tissue. Punches were immersed in lysis buffer containing 25 $\mathrm{mm}$ Tris- $\mathrm{HCl}, \mathrm{pH} 8$, protease inhibitors (pepstatin, leupeptin, aprotinin), and phosphatase inhibitors (sodium pyrophosphate, sodium fluoride, sodium molybdate, phenylarsin oxide, and sodium orthovanadate). The OVLT/SFO and PVN/SON punches were immersed in 50 and $100 \mu \mathrm{l}$ of lysis buffer, respectively. Brain punches were sonicated for $3 \mathrm{~s}$ followed by centrifugation at $14,000 \mathrm{rpm}$ in $4^{\circ} \mathrm{C}$ for $15 \mathrm{~min}$. Supernatant was collected and a bicinchoninic acid (BCA) protein assay was performed on $5 \mu$ l of each sample. Based on the protein levels detected by BCA, appropriate amounts of sample and sample buffer were loaded into wells of a SDS polyacrylamide gel. Western blot for phospho- and totalERK1/2 was performed using the LiCor Odyssey System. The following antibodies were used: phospho-ERK1/2 (Thr202/Tyr204; E10) Mouse mAb no. 9106 (Cell Signaling Technology); Erk 1 Antibody (C-16): sc-93 (Santa Cruz Biotechnology); IRDye 800CW Goat anti-Mouse IgG (H + L; Li-Cor Biosciences); IRDye 680LT Goat anti-Rabbit IgG (H + L; LiCor Biosciences).

Immunohistochemistry. To observe brain activation after DOC and AngII treatments, rats were pretreated twice daily for $3 \mathrm{~d}$ ( $10 \mathrm{~h}$ apart) with vehicle or DOC. On day 4, rats were administered either vehicle or $20 \mathrm{ng}$ AngII intracerebroventricularly. To determine the efficacy of XC in blocking calcium release, rats were injected intracerebroventricularly with vehicle, XC, AngII, or XC plus AngII. To examine the effect PVN inactivation on $\mathrm{cFos}$ expression in other brain areas, rats were injected with either: lidocaine or vehicle in the PVN, followed 5 min later by either: vehicle or $20 \mathrm{ng}$ AngII intracerebroventricularly. Sixty minutes after the last intracerebroventricular injection in each study, each rat was anesthetized with $50 \mathrm{mg} / \mathrm{kg}$ ketamine and $20 \mathrm{mg} / \mathrm{kg}$ xylazine, intraperitoneally (i.p.). They were perfused transcardially with $100 \mathrm{ml}$ of 
heparinized saline followed by $200 \mathrm{ml}$ 4\% paraformaldehyde (Electron Microscopy Sciences). The brains were isolated, postfixed in paraformaldehyde overnight at $4^{\circ} \mathrm{C}$, then submerged in $20 \%$ sucrose in $0.1 \mathrm{M}$ phosphate buffer for $3 \mathrm{~d}$. Coronal sections were cut on a freezing microtome into three serial sets of $40-\mu \mathrm{m}$-thick sections. These slices encompassed the OVLT, SFO, PVN, and SON. One set from each animal underwent immunohistochemical staining and analysis. Rostral-caudal coordinates (relative to bregma) for each brain region analyzed are as follows: OVLT $=+0.60 \mathrm{~mm}$ to $+0.12 \mathrm{~mm}$; SFO $=-0.60 \mathrm{~mm}$ to $-1.44 \mathrm{~mm}$; $\mathrm{PVN}=-1.56 \mathrm{~mm}$ to $-1.92 \mathrm{~mm}$; SON $=-0.48 \mathrm{~mm}$ to $-1.32 \mathrm{~mm}$. These correspond to specific figures in the rat brain atlas (Paxinos and Watson, 1986; OVLT $=$ their Figs. $28-32$, SFO $=$ their Figs. $38-45$, PVN $=$ their Figs. 46-49, SON $=$ their Figs. 37-44. OVLT sections include the dorsal cap and lateral margins as previously described (Oldfield et al., 1994; Bisley et al., 1996). Sections were matched to these atlas coordinates, with four to six sections total per brain region within each animal and six animals per treatment group.

For cFos immunohistochemistry, sections were washed in Trisbuffered saline (TBS), $\mathrm{pH} 7.4$, then incubated with a cFos antibody (1: 500 , sc-52, rabbit; Santa Cruz Biotechnology) in TBS with $0.2 \%$ Triton $\mathrm{X}-100$ and 3\% normal donkey serum (Jackson Immunoresearch) overnight at $4^{\circ} \mathrm{C}$. After several washes, sections were incubated with a biotinSP-conjugated AffiniPure donkey anti-rabbit IgG (1:100, Jackson Immunoresearch) in TBS with $0.2 \%$ Triton X-100 and 3\% normal donkey serum for $2 \mathrm{~h}$ at room temperature. After several washes, sections were incubated with the Vectastain $\mathrm{ABC}$ kit (Vector Laboratories) for $1 \mathrm{~h}$. This was followed by another set of washes before staining with $3^{\prime} 3^{\prime}$-diaminobenzidine (Sigma-Aldrich) for $10 \mathrm{~min}$. After a final set of washes, sections were mounted on slides, air-dried, and coverslipped with DPX mounting media (Electron Microscopy Sciences).

A subset of sections including the OVLT was double-labeled for AngIIinduced cFos and oxytocin immunohistochemistry. Immunohistochemistry was performed as previously described, except with another cFos primary antibody (1:500, sc-8047, mouse, Santa Cruz Biotechnology) and an oxytocin antibody (1:500, T-4084, rabbit; Bachem). The specificity of cFos has been previously reported (Hebert et al., 2005). The oxytocin antibody was raised against the nonapeptide oxytocin (H-CysTyr-Ile-Gln-Asn-Cys-Pro-Leu-Gly- $\mathrm{NH}_{2}$ ). Radioimmunoassay data provided by the manufacturer reported $100 \%$ and $0 \%$ cross-reactivity for oxytocin and vasopressin, respectively. We performed additional specificity tests previously (Griffin et al., 2010), including omission of the primary or secondary antisera, preabsorption with the oxytocin peptide, and the lack of labeling in oxytocin knock-out mice, unlike the sections from wild-type littermates stained in parallel. The lack of cross-reactivity between the labeling of each primary antiserum was verified by the cellular compartmental specificity of cFos versus oxytocin labeling when each was labeled individually: cFos was never observed in fibers, and oxytocin was never localized to the nucleus. The secondary antibodies used for this staining were biotin-SP-conjugated AffiniPure donkey antimouse IgG and donkey-antirabbit IgG (1:100, Jackson Immunoresearch).

Images were acquired with a digital camera (Diagnostic Instruments, model RTKE), maintaining the same microscope and camera settings to ensure the same level of light and exposure for all images. Background was subtracted from images using Photoshop, and images were thresholded to the same level (200). Images were further analyzed in NIH ImageJ using standardized boxes for each brain region (calculated using the rat brain atlas; Paxinos and Watson, 1986), using the analyze particles function. Pixel size minimum was 15 and circularity was set to 0.35 . All image analysis was performed with the experimenter blind to the treatment groups.

Oxytocin secretion. Animals were pretreated twice daily for $3 \mathrm{~d}$ with vehicle or DOC, as described previously. On day 4, rats were administered either vehicle or $20 \mathrm{ng}$ AngII intracerebroventricularly. Two minutes after the last injections, animals were rapidly decapitated and trunk blood was collected into $10 \mathrm{ml} \mathrm{BD} \mathrm{Vacutainer} \mathrm{blood} \mathrm{collection} \mathrm{heparin-}$ ized glass tubes on ice. The tubes then were centrifuged at $4^{\circ} \mathrm{C}$ at 1300 relative centrifugal force for $10 \mathrm{~min}$. The plasma supernatant was extracted with acetone and petroleum ether. Plasma levels of oxytocin and
AVP were measured with a specific radioimmunoassay performed by the laboratory of Dr Joseph G. Verbalis, as described previously (Verbalis et al., 1986). The standard curve for each peptide was linear between 0.25 and $5 \mu \mathrm{U}$ per tube with the oxytocin standard and between 0.5 and 10.0 pg per tube using a synthetic AVP (Bachem Americas). The minimum detectable concentration of oxytocin or AVP in extracted plasma was $0.25 \mu \mathrm{U} / \mathrm{ml}$ and $0.5 \mathrm{pg} / \mathrm{ml}$, respectively. The oxytocin antiserum exhibited $<1 \%$ cross-reactivity with AVP, and the AVP antiserum (R-4) displayed $<1 \%$ cross-reactivity with oxytocin.

Statistical analysis. Data are presented as the mean \pm SEM. For all experiments, comparisons were made between treatment groups (with either a one-way, two-way, or three-way ANOVA). When warranted, planned comparison post hoc $t$ tests were performed. All hypothesis tests used $\alpha=0.05$ as the criterion level of significance. Statistical analyses were conducted using Prism 2.0 software for one-way or two-way ANOVAs and Statistica 12 Ultimate Academic Bundle for three-way ANOVAs.

\section{Results}

\section{The role of ERK1/2 in DOC and AngII-induced sodium appetite}

Consistent with previous research (Fluharty and Epstein, 1983), DOC pretreatment potentiated AngII-induced sodium intake, but not water intake (Fig. $1 A$ ). A two-way ANOVA established a main effect for both AngII $\left(F_{(2,54)}=10.7, p<0.001\right)$ and DOC $\left(F_{(1,54)}=29.6, p<0.001\right)$ on sodium intake, as well as an interaction between the two treatments $\left(F_{(2,54)}=3.2, p=0.046 ; n=\right.$ 12 rats/treatment group). Bonferonni post hoc $t$ tests revealed a significant difference between each dose of AngII and the respective DOC pretreated condition $(p<0.001$ for the 2 ng AngII dose; $p=0.020$ for the $20 \mathrm{ng}$ AngII dose). Regarding water intake, a two-way ANOVA supported a main effect for $\operatorname{AngII}\left(F_{(2,60)}=\right.$ $31.1, p<0.001)$, but not $\operatorname{DOC}\left(F_{(1,60)}=0.7, p=0.400\right)$, to increase water intake.

The role of ERK1/2 in the interaction between AngII and DOC to induce sodium appetite was investigated by using the MEK inhibitor U0126 (Fig. 1B). A three-way ANOVA indicated that there was no interaction between all three variables on sodium intake $\left(F_{(1,153)}=1.5, p=0.222\right)$. However, there was an interaction between DOC and AngII $\left(F_{(1,153)}=8.1, p=0.001\right)$, as reported in Figure $1 A$. Additionally, there was an interaction between the MEK inhibitor and AngII $\left(F_{(1,153)}=3.1, p=0.050\right)$. Specifically, U0126 significantly reduced sodium intake induced by $20 \mathrm{ng}$ AngII alone $(6.6 \pm 1.8$ vs $2.2 \pm 1.0 \mathrm{ml}, p=0.003$; planned comparison $t$ tests; $n=18$ rats/treatment group), as shown previously (Daniels et al., 2009; Felgendreger et al., 2013). However, the MEK inhibitor U0126 did not reduce sodium intake elicited by combined DOC and AngII treatments; in the $2 \mathrm{ng}$ AngII condition, U0126 enhanced DOC/AngII induced sodium appetite $(5.1 \pm 0.9$ vs $8.5 \pm 0.8 \mathrm{ml}, p=0.010$, for the $2.0 \mathrm{ng}$ dose of AngII; $11.3 \pm 1.4 \mathrm{vs} 12.6 \pm 2.3 \mathrm{ml}, p=0.270$, for the $20 \mathrm{ng}$ dose of AngII). U0126 did not diminish the effect of AngII on water consumption.

The effect of these hormonal treatments on the activation of ERK1/2 in OVLT, SFO, PVN, and SON then was measured by Western blot analysis, as shown in Figure 1C. A two-way ANOVA supported a main effect of AngII alone, but not DOC alone, on ERK $1 / 2$ phosphorylation $\left(F_{(2,20)}=4.1, p=0.030 ; n=6\right.$ rats $/$ treatment group) for both OVLT/SFO and PVN/SON. Post hoc tests revealed that both doses of AngII significantly increased phospho-ERK1/2 compared with vehicle treatment (OVLT/SFO: $0.5 \pm 0.0$ and $0.5 \pm 0.0$ vs $0.3 \pm 0.0, p=0.049$ and 0.043 ); PVN/SON: $0.5 \pm 0.0$ and $0.4 \pm 0.0$ vs $0.3 \pm 0.0, p=0.025$ and 0.048 ). Additionally, there was a significant interaction between 
A
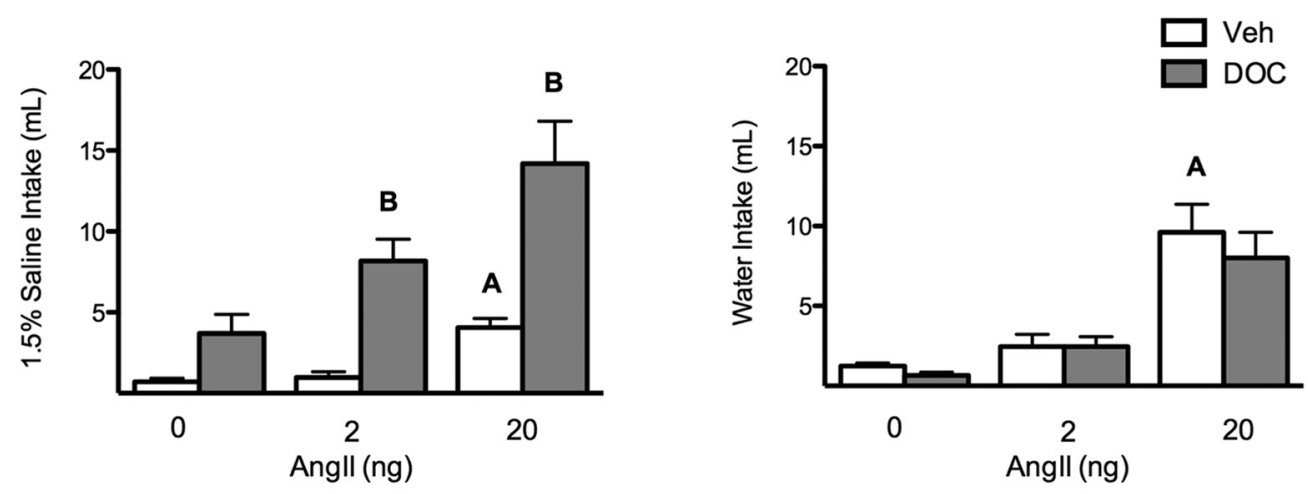

B
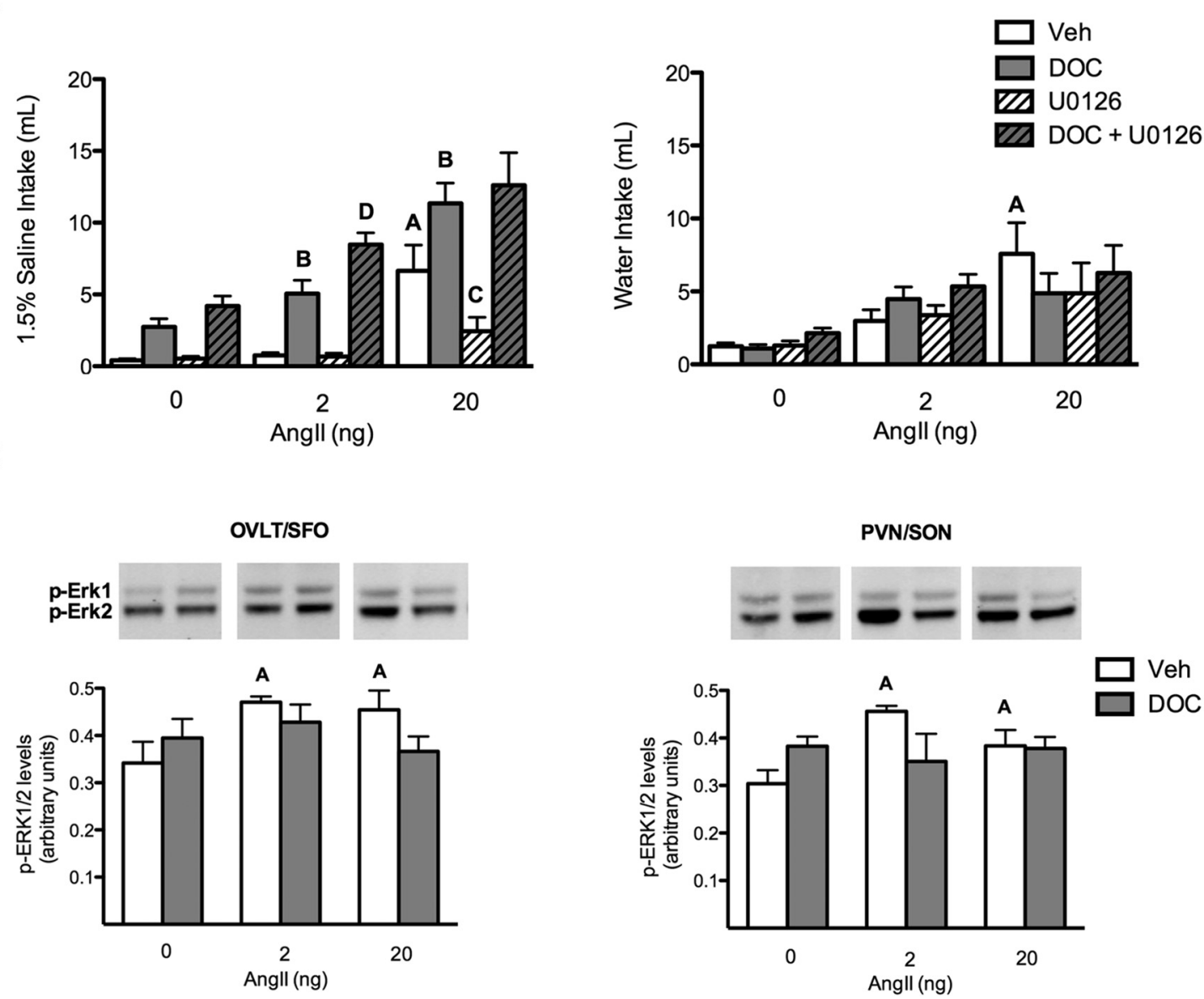

Figure 1. Erk1/2 is not necessary for the DOC/Angll potentiation of sodium appetite. $A$, Bar graphs illustrating the potentiation of Angll-induced sodium but not water intake by DOC $(n=$ 12/group). B, Bar graphs illustrating the effect of blocking ERK1/2 activation on DOC and Angll-induced sodium and water intake ( $n=18 /$ group). DOC potentiated 2 and $20 \mathrm{ng}$ Angll-induced sodium intake. This behavior was not reduced by the MEK inhibitor U0126; however, U0126 reduced sodium intake with $20 \mathrm{ng}$ Angll alone. Angll-induced water intake was not potentiated by DOC. C, Bar graphs illustrating phosphorylated ERK1/2 levels in the OVLT/SF0 and PVN/SON after either oil or DOC pretreatment followed by intracerebroventricular treatments with 2 or $20 \mathrm{ng}$ Angll ( $n=$ 6/group). Angll treatment induced significant ERK1/2 phosphorylation compared with vehicle in both sets of brain regions. DOC pretreatment did not enhance this activation. Representative Western blot images of ERK1/2 phosphorylation are shown above each quantified bar. For the sake of clarity, only specific statistical differences are highlighted. " $\mathrm{A}$ " indicates Angll is different from vehicle; " $\mathrm{B}$ " indicates DOC/Angll is different from Angll; " $C$ " indicates U0126/Angll is different from Angll; and " $\mathrm{D}$ " indicates U0126/DOC/Angll is different from DOC/Angll, $p<0.05$. Veh, Vehicle.

DOC and AngII treatments for these brain regions (OVLT/SFO: $F_{(2,20)}=4.1, p=0.031 ;$ PVN/SON: $\left.F_{(2,20)}=3.9, p=0.035\right)$, such that in the presence of DOC, AngII treatment no longer activated ERK1/2. In short, these results did not support the hypothesis that DOC potentiated the effects of central AngII on sodium appetite by further increasing phospho-ERK1/2 levels in relevant brain regions. Nevertheless, the negative interaction between DOC and AngII on ERK1/2 activation in circumventricular and neuroendocrine regions suggested that further investigation of these areas was warranted.

The interaction of DOC and AngII on cFos activation in the brain

To further explore the neurological mechanisms that underlie the behavioral cooperativity of DOC and AngII, cFos immunohistochemistry was used to detect a unique pattern of brain activity 
A
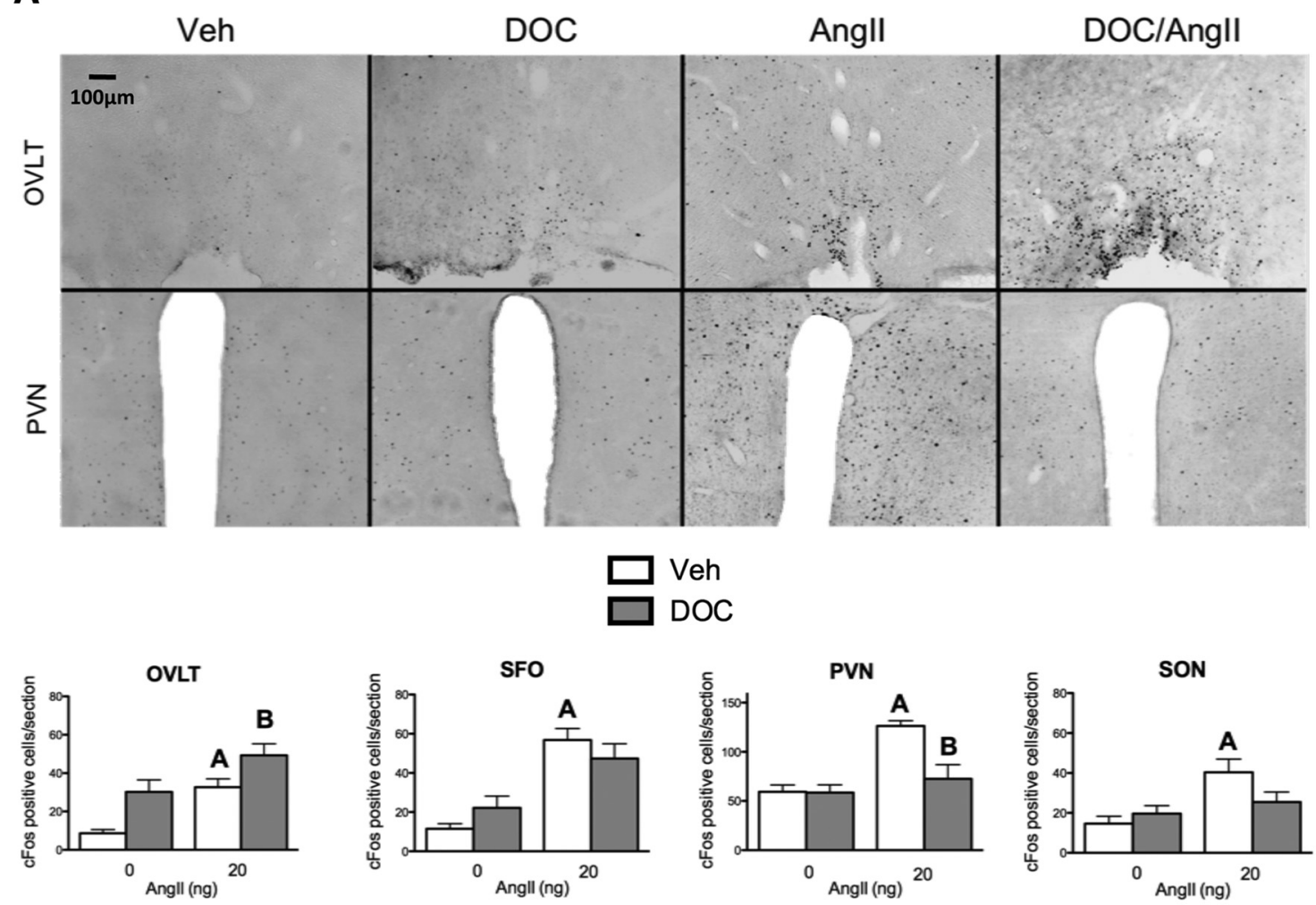

\section{B}
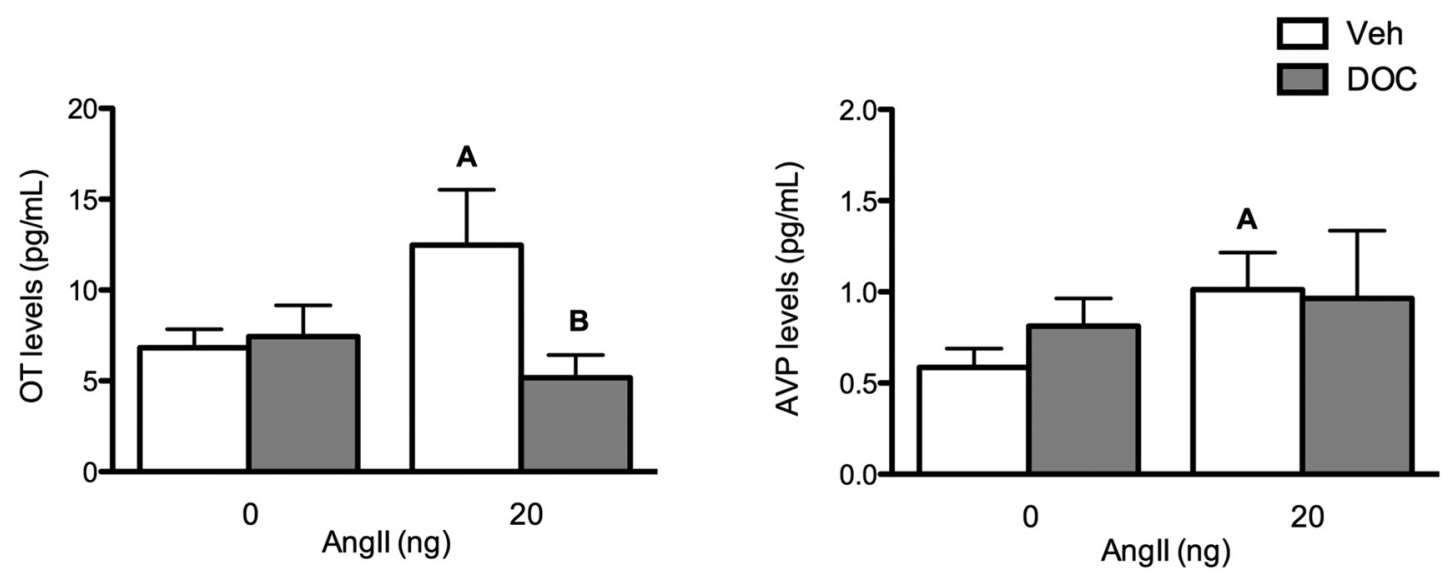

Figure 2. DOC pretreatment enhanced Angll-induced OVLT activation and reduced PVN activity and oxytocin (OT) release. A, Bar graphs illustrating cFos cell counts in different brain areas (OVLT, SFO, PVN, and SON) after either vehicle or DOC pretreatment followed by intracerebroventricular vehicle or $20 \mathrm{ng}$ Angll ( $n=6 /$ group). In the OVLT, each treatment condition induces (Fos immunostaining compared with vehicle; DOC/Angll induced additional cFos immunostaining. In the SFO, both Angll alone and DOC/Angll induced more cFos staining than either vehicle or DOC alone. cFos labeling in the PVN was increased by Angll, but DOC reduced the Angll-induced cFos expression to control levels. In the SON, Angll induced cFos staining. Representative images of the OVLT and PVN (coronal plane, $10 \times$ ) in each treatment condition are shown above the bar graphs. Representative images of SF0 and SON are not shown, but similar data were seen. $\boldsymbol{B}$, Bar graphs illustrating oxytocin and AVP plasma levels after either vehicle or DOC pretreatment followed by intracerebroventricular vehicle or $20 \mathrm{ng}$ Angll $(n=8 / \mathrm{group})$. Angll treatment increased oxytocin levels, and this effect was reduced by DOC pretreatment. However, Angll treatment elevated AVP levels, regardless of pretreatment. For the sake of clarity, only specific statistical differences are highlighted. "A" indicates Angll is different from vehicle; " $B$ " indicates DOC/Angll is different from Angll. Veh, Vehicle.

that might correspond to the behavioral effects of these hormones. As illustrated in Figure $2 A$, brain sections from OVLT, $\mathrm{SFO}, \mathrm{PVN}$, and SON were analyzed for cFos immunolabeling. In the OVLT, a two-way ANOVA revealed a main effect for both AngII and DOC on cFos expression $\left(F_{(1,17)}=16.4, p<0.001\right.$; $F_{(1,17)}=12.8, p=0.002 ; n=6$ rats/treatment group, $4-6$ sections per brain area). Bonferonni post hoc tests indicated that cFos levels were significantly enhanced compared with vehicle for all treatment groups (vehicle: $8.7 \pm 1.9$, DOC: $30.2 \pm 6.3$, AngII:
$32.7 \pm 4.4$, DOC and AngII: $49.3 \pm 6.0 ; p=0.021, p=0.003, p<$ $0.001)$. In the SFO, a two-way ANOVA indicated a main effect for AngII on cFos expression $\left(F_{(1,16)}=32.5, p<0.001\right)$. Bonferonni post hoc tests noted that $\mathrm{cFos}$ levels were similar for vehicle and DOC, but both AngII and DOC/AngII treatments significantly enhanced staining (vehicle: $11.5 \pm 2.6$, DOC: $22.1 \pm 6.0$, AngII: $56.8 \pm 5.9$, DOC and AngII: $47.4 \pm 7.6 ; p=0.200, p=0.001, p=$ $0.004)$. In the PVN, a two-way ANOVA revealed a main effect for AngII, DOC, and an interaction between the two variables on 
cFos expression $\left(F_{(1,18)}=16.4, p<0.001 ; F_{(1,18)}=7.5, p=0.014\right.$, $\left.F_{(1,18)}=7.0, p=0.016\right)$. Bonferonni post hoc tests indicated that AngII significantly increased cFos staining compared with vehicle in the PVN $(126.3 \pm 5.3$ vs $59.4 \pm 6.9, p<0.001)$, and DOC reduced AngII-induced cFos staining to vehicle levels (126.3 \pm 5.3 vs $72.5 \pm 14.4, p=0.006)$. In the $\mathrm{SON}$, a two-way ANOVA revealed a main effect for AngII on cFos expression $\left(F_{(1,16)}=7.9\right.$, $p=0.013)$. Post hoc tests indicated that AngII induced a significant amount of cFos staining compared with vehicle (40.4 \pm 6.6 vs $14.6 \pm 3.7, p=0.020)$. There was a trend for DOC to reduce AngII-induced Fos staining compared with AngII alone (25.4 \pm 5.0 vs $40.4 \pm 6.6, p=0.100)$. In short, the most striking interactions between DOC and AngII on cFos labeling were the enhanced cFos staining in the OVLT and the suppressed cFos levels in the PVN.

The observation that DOC diminished the AngII-induced Fos activation in the PVN is reminiscent of previous studies that demonstrated that DOC inhibits oxytocin neuron activity in the PVN, thereby disinhibiting sodium intake (Roesch et al., 2001). We tested whether the DOC treatment was associated with alterations in AngII-induced neurohypophysial secretion. Plasma levels of oxytocin and AVP were measured by radioimmunoassay after DOC, AngII, or both hormone treatments, 2 min after the AngII treatment (Fig. 2B). A two-way ANOVA revealed a main effect for both AngII and DOC, as well as an interaction between the two hormones on oxytocin secretion $\left(F_{(1,27)}=4.2, p=0.049\right.$; $F_{(1,27)}=4.4, p=0.045 ; F_{(1,27)}=5.7, p=0.020, n=8$ rats $/$ treatment group). AngII increased oxytocin levels significantly compared with vehicle $(12.8 \pm 2.9$ vs $6.4 \pm 0.8 \mathrm{pg} / \mathrm{ml}, p=0.048)$. DOC reduced these AngII-induced oxytocin levels back down to control levels $(12.8 \pm 2.9$ vs $5.1 \pm 1.2 \mathrm{pg} / \mathrm{ml}, p=0.035)$. In contrast, there was no effect of DOC on AngII-induced AVP secretion.

Together, these results demonstrate parallel changes in cFos expression in the OVLT, PVN oxytocin activity, and the natriorexic effect of combined DOC and AngII. We next sought to determine whether disruption of cFos induction in the OVLT with an IP3 receptor antagonist would impair the behavioral cooperativity of DOC and AngII.

\section{The role of IP3 in DOC and AngII-induced sodium appetite}

IP3 signaling was blocked with an antagonist to the IP3 receptor, namely XC. First the bioactivity of centrally administered XC was verified by assaying AngII-induced cFos immunohistochemistry in Figure $3 A$. Given that $c$ Fos is an immediate early gene activated by IP3-induced intracellular calcium signaling, an effective IP3 receptor antagonist should prevent calcium signaling, and thereby cFos expression (Clark et al., 1992; Templeton et al., 1998; Jomphe et al., 2003; Daniels et al., 2005; Zhang et al., 2012). A two-way ANOVA indicated main effects of AngII and XC, and an interaction on $\mathrm{cFos}$ expression $\left(F_{(1,17)}=6.0, p=0.026 ; F_{(1,17)}\right.$ $=6.0, p=0.026 ; F_{(1,17)}=5.7, p=0.029$; respectively) in the OVLT ( $n=6$ rats/treatment group, $4-6$ sections per brain area). In particular, Bonferroni post hoc tests suggest that XC pretreatment significantly reduced the number of AngII-induced cFoslabeled neurons ( $35.8 \pm 5.2$ vs $11.7 \pm 1.6, p=0.002)$. Labeling in the SFO exhibited a main effect for AngII, but not XC $\left(F_{(1,15)}=\right.$ 7.2, $\left.p=0.020 ; F_{(1,15)}=0.9, p=0.360\right)$. However, there was a significant interaction between AngII and XC $\left(F_{(1,15)}=5.3, p=\right.$ $0.040)$. Specifically, Bonferonni post hoc tests designated a significant reduction in cFos expression between AngII and XC plus AngII $(30.0 \pm 4.3$ vs $15.1 \pm 4.3, p=0.035)$.

Having demonstrated that the XC treatment effectively blocked IP3-induced cFos in relevant brain regions, the role of
IP3 in AngII and DOC induced sodium appetite was investigated (Fig. $3 B$ ). A three-way ANOVA indicated that sodium intake differed between treatment groups $\left(F_{(1,68)}=6.5, p=0.010 ; n=\right.$ $10 \mathrm{rats} /$ treatment group). Consistent with Figure 1, DOC enhanced AngII-induced sodium intake $(p=0.006)$. XC did not affect sodium ingestion in animals treated with AngII alone $(8.3 \pm 1.8$ vs $8.3 \pm 1.7 \mathrm{ml}, p=0.990)$. However, $\mathrm{XC}$ reduced the DOC and AngII enhancement of sodium intake to levels similar to the AngII alone group $(15.1 \pm 1.3$ vs $10.9 \pm 1.3 \mathrm{ml}, p=0.030)$. Likewise, a three-way ANOVA revealed that water intake differed between treatment groups $\left(F_{(1,51)}=5.8, p=0.020\right)$. Post hoc tests indicated that XC reduced AngII-induced water intake (11.0 \pm 1.6 vs $6.9 \pm 1.0 \mathrm{ml}, p=0.030)$. However, when both DOC and AngII were present, $\mathrm{XC}$ did not reduce water intake $(8.7 \pm 1.1 \mathrm{vs}$ $9.2 \pm 1.8 \mathrm{ml}, p=0.810)$. Together, these results suggest that IP3 signaling, possibly in the OVLT, is necessary for the cooperative actions of DOCA and AngII on sodium appetite. Previous work suggested that DOC enhances AngII-induced sodium appetite via the suppression of oxytocin activity in the PVN (Stricker and Verbalis, 1987; Blackburn et al., 1992a), and several findings reported here are consistent with that hypothesis. Therefore, the next experiment was designed to manipulate PVN activity and measure the effect on sodium appetite and neuronal activation in the OVLT.

\section{Sodium appetite and OVLT activation after suppression of PVN activity}

Neural activity in the PVN was suppressed with bilateral injections of lidocaine above the PVN. Behavioral analysis included only animals with cannula tract locations verified to be above the PVN (Fig. 4A). Animals were treated with either vehicle or lidocaine into the PVN, followed by either vehicle or AngII (20 ng, i.c.v.). A two-way ANOVA revealed a main effect for AngII and lidocaine, as well as an interaction on sodium intake $\left(F_{(1,20)}=\right.$ 21.5, $p=0.001 ; F_{(1,20)}=5.2, p=0.035 ; F_{(1,20)}=6.7, p=0.020$; $n=10$ rats/treatment group). As shown in Figure $4 B$, AngII increased sodium intake compared with vehicle $(5.6 \pm 1.0$ vs $2.0 \pm 0.6 \mathrm{ml}, p=0.040$ ). Additionally, lidocaine enhanced AngIIinduced sodium intake significantly $(9.5 \pm 1.2 \mathrm{vs} 5.5 \pm 1.4 \mathrm{ml}$ $p=0.045)$. Conversely, a two-way ANOVA revealed a main effect for AngII but not lidocaine on water intake $\left(F_{(1,23)}=28.8, p<\right.$ $\left.0.0001 ; F_{(1,23)}=0.1, p=0.740\right)$. Post hoc tests denoted AngII plus or minus lidocaine-treated rats drank very similar amounts of water $(9.1 \pm 1.5$ vs $8.6 \pm 1.0 \mathrm{ml}, p=0.760)$, but both groups drank significantly more than vehicle-treated rats $(0.5 \pm 0.5 \mathrm{ml}$, $p=0.02$ and $p=0.009)$. A subset of rats was treated with oxytocin (10.0 $\mu$ g, i.c.v.) in the lidocaine plus AngII condition. Oxytocin coadministration decreased sodium intake to vehicle levels $(9.5 \pm 1.2$ vs $2.1 \pm 0.7 \mathrm{ml}, p=0.001)$. However, oxytocin treatment also partially decreased water intake in the lidocaine plus AngII group $(8.6 \pm 1.0$ vs $4.7 \pm 1.2 \mathrm{ml}, p=0.030)$. In summary, lidocaine in the PVN enhanced AngII-induced sodium intake, but not water intake, mimicking the effects of DOC pretreatment.

After the behavioral studies, AngII-induced cFos immunohistochemistry was performed on the brains of these animals to verify the efficacy of lidocaine administration to the PVN and to test the hypothesis that PVN activity may restrain sodium appetite by inhibiting neural activity in the OVLT (Fig. 4C). Based on the behavioral results, these treatments were selected for comparison: vehicle/vehicle; vehicle/AngII; and lidocaine/AngII. Oneway ANOVA indicated that cFos expression in the OVLT differed between treatment groups $\left(F_{(2,21)}=34.47, p<0.001 ; n=6\right.$ rats/treatment group, $4-6$ sections per brain area). Post hoc tests 
A

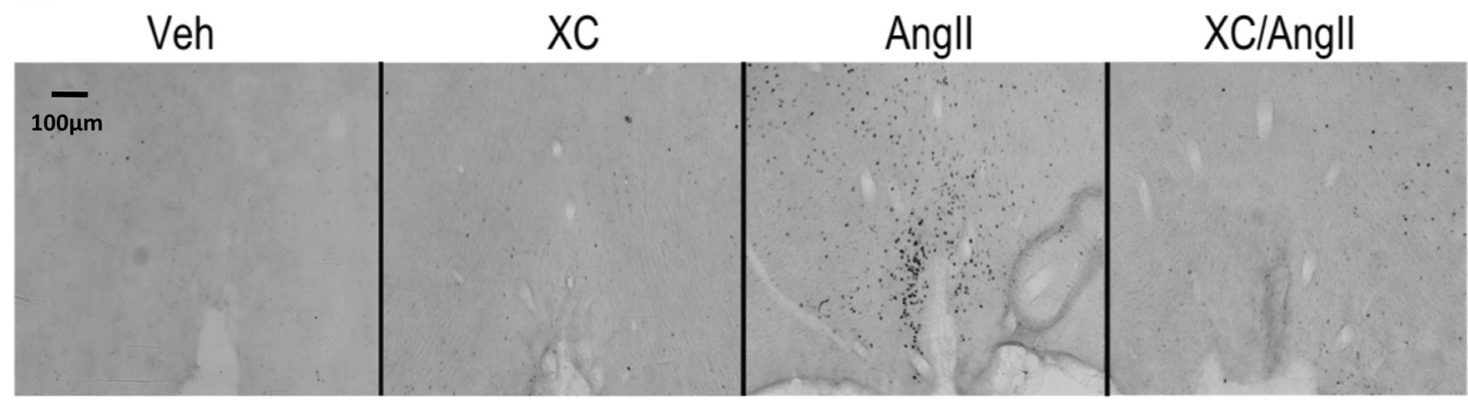

OVLT

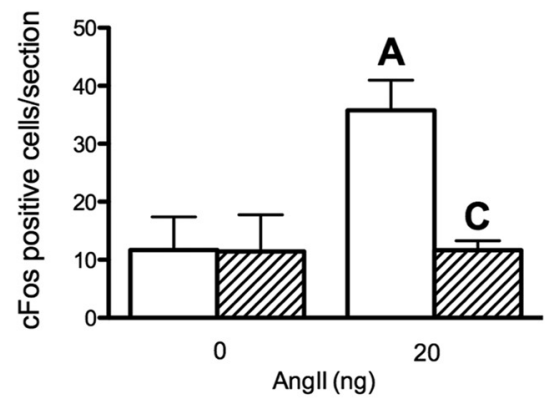

B

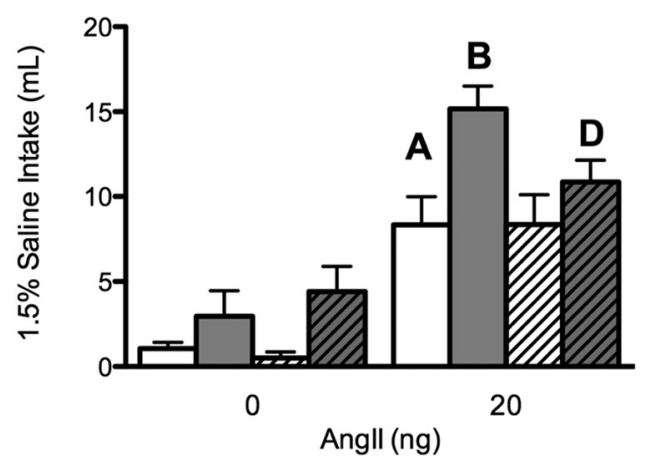

SFO
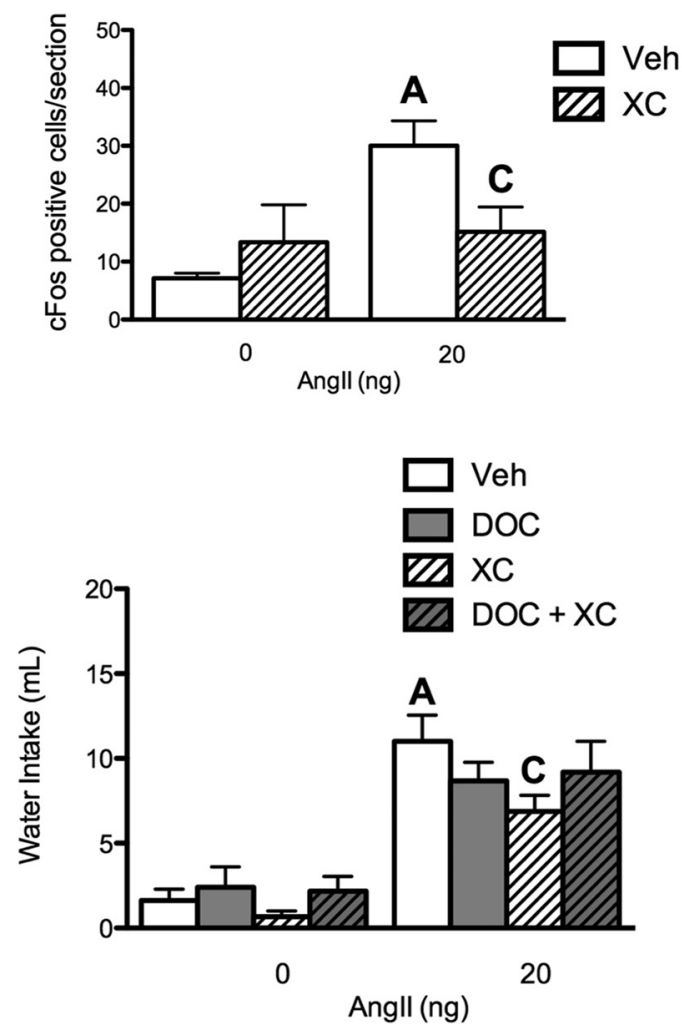

Figure 3. The IP3 receptor is required for DOC/Angll potentiation of sodium appetite. A, Bar graphs illustrating the level of cFos expression in the OVLT and SFO after vehicle, XC, $20 \mathrm{ng}$ Angll, or $X C$ plus $20 \mathrm{ng}$ Angll intracerebroventricularly ( $n=6$ /group). Representative images of cFos staining of OVLT coronal sections $(10 \times)$ in each treatment group are shown above the graphs. Representative images of the SFO are not shown, but similar data were seen. Angll induced cFos staining in both the OVLT and SFO, and the effect was reduced by XC. $B$, Bar graphs illustrating the effect of XC on DOC and $20 \mathrm{ng}$ Angll induced sodium and water intake ( $n=10 /$ group). DOC potentiates Angll-induced sodium intake; this effect was impaired by the IP 3 receptor inhibitor XC. XC did not affect sodium intake induced by Angll alone. Angll-induced water intake was reduced by XC. For the sake of clarity, only specific statistical differences are highlighted. " $\mathrm{A}$ " indicates Angll is different from vehicle; " $\mathrm{B}$ " indicates DOC/Angll is different from Angll; " $C$ " indicates $X C /$ Angll is different from Angll; " $\mathrm{D}$ " indicates $X C / D O C / A n g l l$ is different from DOC/Angll; $p<0.05$. Veh, vehicle.

indicated that lidocaine further enhanced $20 \mathrm{ng}$ AngII-induced cFos expression in the OVLT (33.29 \pm 3.0 vs $54.60 \pm 3.0, p=$ 0.001 ), emulating the effects seen with DOC pretreatment. Additionally, cFos expression in the PVN was reduced with lidocaine pretreatment, illustrating reduced PVN activity (140.6 \pm 15.6 vs $88.5 \pm 3.5, p=0.010$ ).

The previous experiments implicate the OVLT in the control of sodium appetite, in possible relation with centrally released oxytocin, a key inhibitor of sodium appetite. Although oxytocin receptor mRNA has been described in the OVLT (Yoshimura et al., 1993), the physiological delivery of oxytocin to the OVLT remains unclear. As shown in Figure 5, varicose oxytocinimmunoreactive fibers are present in the OVLT. In particular, the oxytocinergic fibers are abundant in the dorsal cap of the OVLT in close association with neurons expressing AngII-induced cFos.

\section{Discussion}

Classic studies showed that AngII and adrenal steroids work cooperatively to elicit a robust salt appetite when elevated concurrently, as occurs during hypovolemia and sodium depletion (Stricker and Wolf, 1966; Stricker, 1966, 1971; Epstein, 1982; Toth et al., 1987). This potentiation of sodium appetite has been observed in various species and is not secondary to natriuresis (Fluharty and Epstein, 1983; Massi and Epstein, 1990; Shade et al., 2002). Experiments with agonists and antagonists confirmed the validity of the "synergy hypothesis" in situations in which the appetite was associated with elevated endogenous levels of AngII and aldosterone (Sakai et al., 1986). The present report initially tested the hypothesis that DOC and AngII actions converge on the ERK1/2 signaling pathway, given that adrenal steroids can 
A

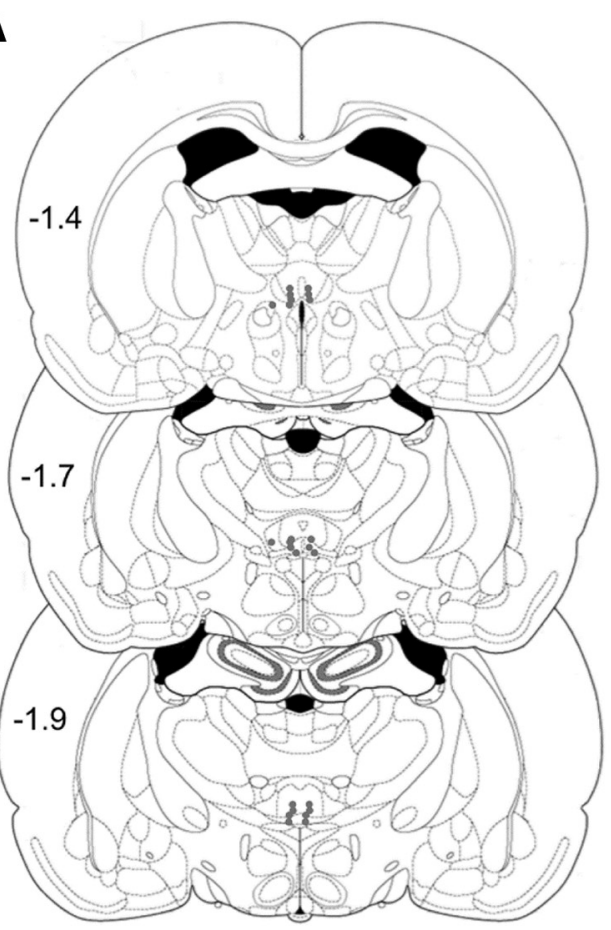

B
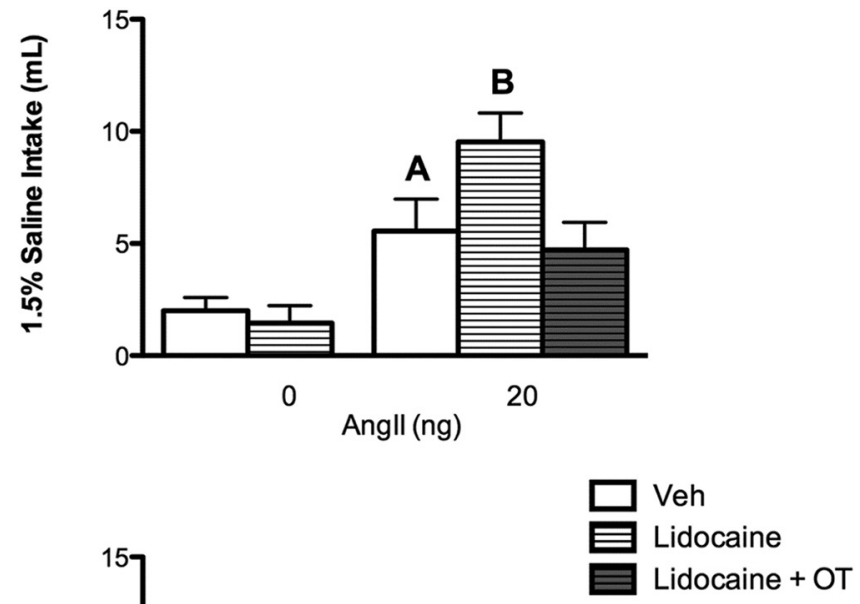

C

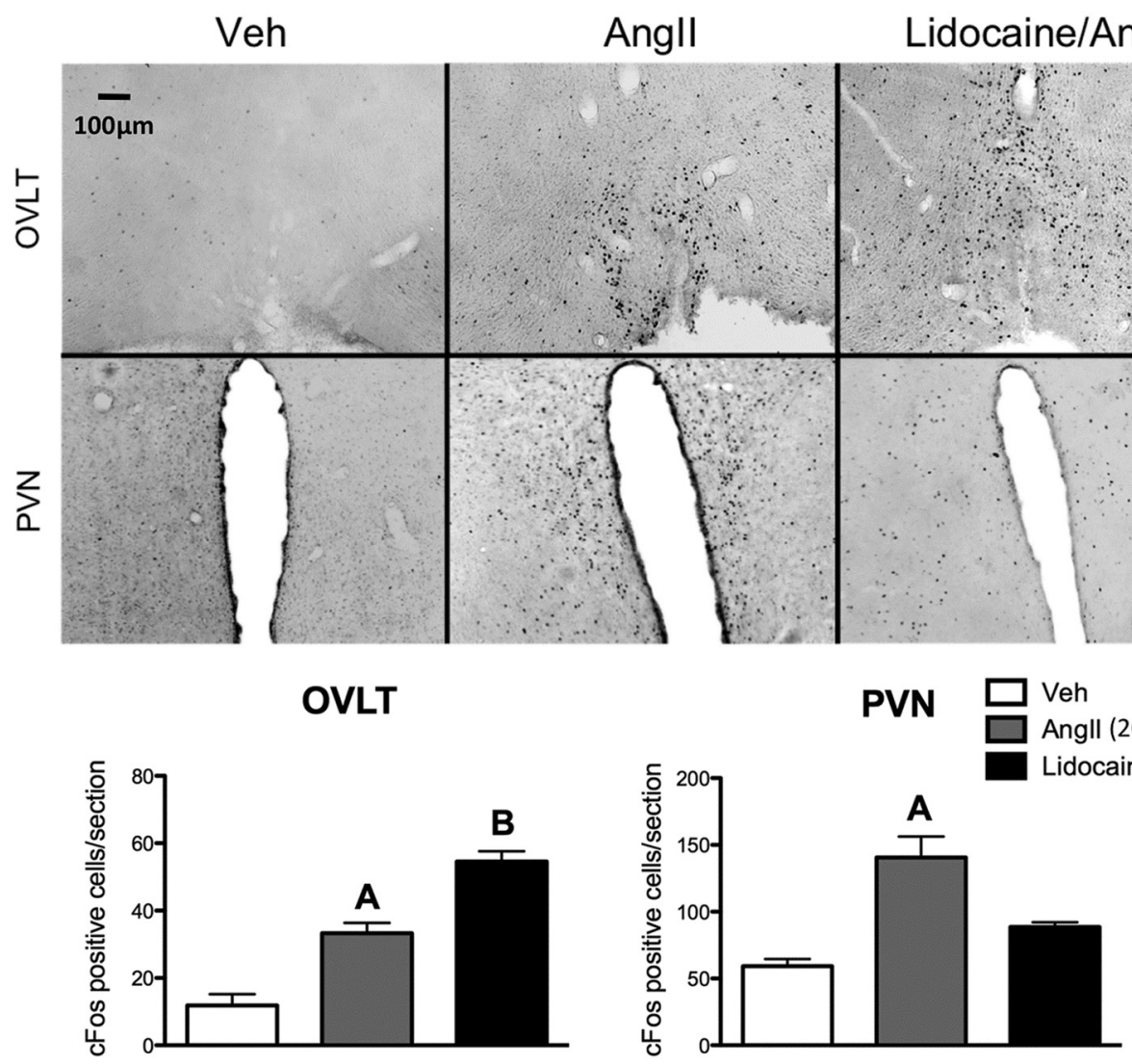

Figure 4. PVN inactivation enhances Angll-induced sodium appetite. $A$, Illustration of rat coronal brain slices depicting bilateral guide cannula placements (filled circles) above the PVN for lidocaine administration. Each pair of dots represents data from one animal. $\boldsymbol{B}$, Bar graphs illustrating the effect of intra-PVN lidocaine on $20 \mathrm{ng}$ Angll-induced sodium and water intake $(n=$ 10/group). Lidocaine-treated animals increased their Angll-induced sodium intake, but not water intake, mimicking the effects of DOC. C, Bar graphs illustrating cFos expression in the OVLT and PVN after vehicle, lidocaine, $20 \mathrm{ng}$ Angll, or lidocaine plus $20 \mathrm{ng}$ Angll intracerebroventricularly ( $n=6 /$ group). Representative images of cFos staining of OVLT and PVN coronal sections (10 $\times$ ) in each treatment group are shown above the graphs. Angll-induced cFos immunostaining was enhanced by lidocaine in the OVLT and reduced in the PVN. For the sake of clarity, only specific statistical differences are highlighted. " $A$ " indicates Angll is different from vehicle; " $B$ " indicates lidocaine/Angll is different from Angll. Veh, Vehicle. 
A

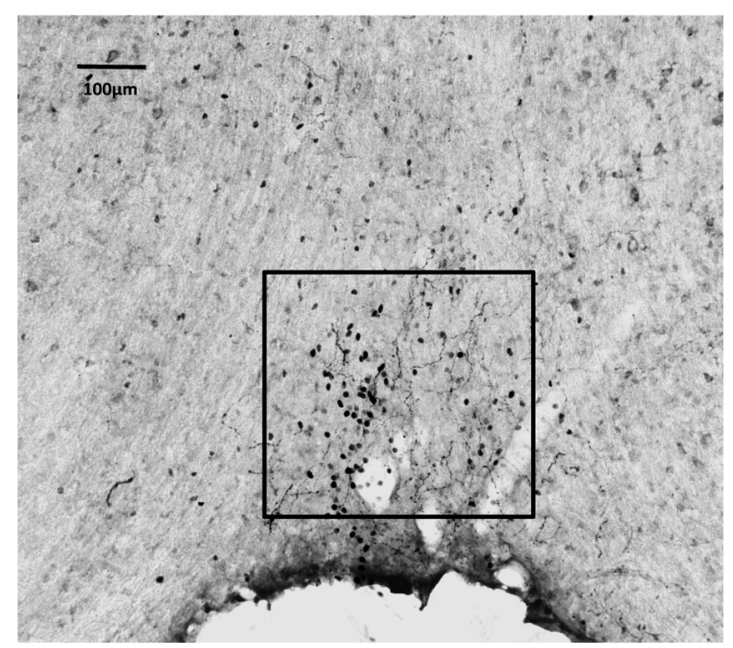

B

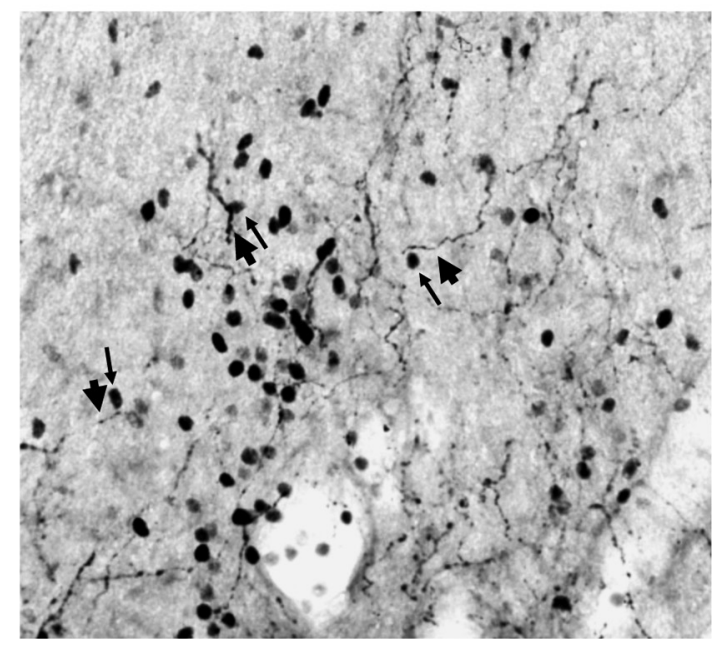

Figure 5. Oxytocin fibers are closely associated with Angll-induced cFos in the dorsal cap of the OVLT. $A$, Representative image of oxytocin and cFos staining of an OVLT coronal section (10 $\times$ ) in an Angll-treated animal. $\boldsymbol{B}$, Magnified image of the dorsal cap of the OVLT (from the box drawn in $\boldsymbol{A}$ ). Thin and thick arrows indicate certain cFos nuclei and OVLT fibers, respectively, that are juxtaposed throughout the dorsal cap.

increase AT1R expression (Ullian et al., 1992; Harada et al., 2001; Mazak et al., 2004) and enhance their cellular signaling (Lemarié et al., 2008, 2009). However, behavioral and biochemical studies did not support this hypothesis. Rather, IP3 signaling, which did not mediate the sodium appetite induced by either hormone alone, was necessary for the behavioral cooperation. Functional neuroanatomy analysis revealed that the combined DOC and AngII treatment suppressed cFos activation in the PVN, reduced neurosecretion of oxytocin, and augmented cFos expression in the OVLT. This led to the novel hypothesis that DOC-induced suppression of oxytocin neural activity in the PVN relieves inhibition in the OVLT to allow a robust sodium ingestion. Local lidocaine administration into the PVN, which prevented AngII-induced cFos expression in the PVN, concomitantly elevated sodium appetite and cFos activation in the OVLT. Finally, immunohistochemical analysis demonstrated that the OVLT is well supplied with oytocin fibers, especially in the vicinity of AngII-induced cFos expression. Thus, the present studies provide further support for an inhibitory signal arising from the oxytocin neurons in PVN and provide novel evidence that oxytocin may act in the OVLT.

\section{Lack of support for an amplification of ERK1/2 signaling}

Central AngII administration activates ERK1/2 in the SFO and PVN (Wei et al., 2009), and ERK1/2 signaling is specifically required for the sodium appetite that emerges after exogenous AngII treatment (Daniels et al., 2005) and endogenous AngII production (Felgendreger et al., 2013). Thus, we hypothesized that ERK1/2 also would be critical for the cooperative effect of DOC and AngII on sodium intake. Behavioral pharmacology and signaling biochemistry experiments, although replicating the previous finding of AngII-induced ERK1/2 and ERK1/2-dependent sodium appetite, did not support a role for ERK1/2 in the combined effect of DOC and AngII. One interpretation of this result is that DOC removes both excitatory and inhibitory effects of AngII. On the contrary, DOC enhances AngIIinduced cFos expression in the OVLT, suggesting that at least some excitatory effects of AngII remain and may contribute to the behavioral synergy.

\section{The interaction of DOC and AngII on IP3-mediated cFos induction}

The AT1R is coupled with intracellular IP3 formation (Smith et al., 1984; Enjalbert et al., 1986; Taylor et al., 1990; Beresford and Fitzsimons, 1992), which in turn acts on the IP3 receptor on the endoplasmic reticulum to liberate intracellular calcium as a third messenger (Nabika et al., 1985; Capponi et al., 1988; Suárez et al., 2002). One consequence of calcium mobilization is transcription of immediate early genes, including cFos (Clark et al., 1992; Templeton et al., 1998; Jomphe et al., 2003; Daniels et al., 2005; Zhang et al., 2012). Central administration of AngII activates cFos expression in several brain regions, including the OVLT, SFO, PVN, and SON (Blackburn et al., 1992a; Herbert et al., 1992; McKinley et al., 1992a), as replicated here. In agreement with previous work (Blackburn et al., 1992a), DOC pretreatment diminished AngII-induced cFos in the PVN and oxytocin neurosecretion. The novel finding that DOC pretreatment increases cFos expression in the OVLT represents a striking parallel with the behavioral effects of DOC and AngII on sodium ingestion. The OVLT is included in the region referred to as the anteroventral third ventricle, and partial damage to this region disinhibits sodium appetite (Andersson et al., 1975; Gardiner et al., 1986; Fitts et al., 1990; Fitts, 1991). IP3 receptor activation was necessary for the DOC and AngII cooperativity on sodium intake, without affecting the sodium ingestion stimulated by either hormone alone.

These three findings may be considered together: (1) the IP3 signaling pathway is uniquely necessary for the DOC and AngII cooperative effect on sodium appetite; (2) its downstream effector in the OVLT, cFos, is highest with combined DOC and AngII treatment, unlike cFos labeling in the other brain regions studied; and (3) PVN activity and oxytocin release are suppressed during the cooperative stimulation of sodium appetite. A parsimonious explanation of these results, partially supported by previous studies, would be that DOC treatment inhibits oxytocin neurons in the PVN, which in turn relieves inhibition on a subset of OVLT neurons, which then augments the drive for sodium ingestion based on IP3 signaling. 


\section{The role of oxytocin in sodium appetite}

A model has been proposed in which centrally acting AngII simultaneously stimulates and inhibits sodium appetite, with the inhibition caused by oxytocin release in the brain (Stricker and Verbalis, 1987, 1996; Blackburn et al., 1992a). Other investigators also have observed a disinhibition of sodium appetite after central administration of an oxytocin antagonist or in knock-out mice (Chow et al., 1997; Puryear et al., 2001; Fitts et al., 2003), although the enhancement of the sodium appetite by an oxytocin antagonist may be somewhat dependent on the dose of AngII (Fitts et al., 2003; Stricker and Verbalis, 2004). The present results replicate several key findings, including the dampening of AngIIinduced cFos activation of the PVN and oxytocin release by DOC pretreatment. However, the site of oxytocin action to inhibit sodium appetite had been unknown.

The discovery that DOC treatment uniquely enhanced the effect of AngII on cFos expression in the OVLT suggests that it is the target of the oxytocinergic inhibition of sodium appetite. Indeed, oxytocin receptor mRNA is localized to the OVLT (Yoshimura et al., 1993). Here, we have demonstrated oxytocin fibers disbursed throughout the dorsal cap of the OVLT. The OVLT includes osmosensitive neurons and is thought to function as the brain's primary osmostat (Denton et al., 1996; Johnson et al., 1996). Many neurons in the OVLT are excited by hypertonicity and inhibited by hypotonicity (Sayer et al., 1984; Honda et al., 1990; Vivas et al., 1990; Nissen et al., 1993), mediated by members of the transient receptor potential vanilloid proteins (Ciura and Bourque, 2006). The OVLT sends both GABAergic and glutamatergic projections to a variety of brain regions (Camacho and Phillips, 1981; Richard and Bourque, 1996), although the functions of these projections remain ill-defined. The present results build on this body of work by correlating the suppression of PVN activity, by either DOC or lidocaine, with increased activation in OVLT neurons. Given that the natriorexic effect of PVN inhibition was reversed with central oxytocin administration, oxytocin is likely the critical inhibitory signal arising from the PVN. Thus, the OVLT, a key sensor of body fluid parameters may also be the target of oxytocin modulation of sodium appetite.

It has been proposed that central oxytocin actions are based on bulk transmission, such as dendritic release in the PVN (Ludwig et al., 2002). Although this mechanism may apply to some situations, oxytocinergic synaptic contacts have been demonstrated in the ventromedial hypothalamus (Griffin et al., 2010). Despite its close proximity to ventricular space, the OVLT has a generous supply of varicose axons containing oxytocin, suggesting local release. Tract tracing studies will be valuable to identify the specific population of oxytocin neurons that directly innervate the OVLT.

Our results suggest that oxytocin neurons, rather than autonomic or vasopressin neurons, explain the changes of sodium appetite after PVN-lidocaine administration. Although lidocaine administered into the PVN could potentially reduce blood pressure via reduced sympathetic activity and vasopressin release, hypotension is an unlikely cause of the PVN-lidocaine-induced sodium appetite. In particular, hypotension would also stimulate water intake, which did not occur.

\section{Interpretational limitations}

The present work focused on the OVLT, SFO, PVN, and SON, based on previous studies. Brainstem, limbic, gustatory, and other hypothalamic regions are certainly involved, but their contributions were beyond the scope of this study. Likewise, the analysis of cFos expression and the pharmacological disruption of neural activity do not fully address the cascade of information processing within the broader neural network. Given that many hypothalamic areas are reciprocally connected, further studies will be needed to disambiguate the roles that these brain regions play in promoting and inhibiting sodium appetite.

\section{Conclusions}

These results rule out the ERK1/2 signaling pathway as an underlying mechanism for DOC-AngII enhancement of sodium appetite. Instead, IP3 signaling is required for the cooperativity of DOC and AngII. Activity in the OVLT and PVN are inversely related, suggesting an inhibitory signal from the PVN to the OVLT. Oxytocin fibers woven throughout the dorsal cap of the OVLT suggest a direct, inhibitory oxytocin input to the OVLT.

\section{References}

Akaishi T, Negoro H, Kobayasi S (1980) Responses of paraventricular and supraoptic units to angiotensin II, sar 1-ile8-angiotensin II and hypertonic $\mathrm{NaCl}$ administered into the cerebral ventricle. Brain Res 188:499-511. CrossRef Medline

Andersson B, Leksell LG, Lishajko F (1975) Perturbations in fluid balance induced by medially placed forebrain lesions. Brain Res 99:261-275. CrossRef Medline

Beresford MJ, Fitzsimons JT (1992) Intracerebroventricular angiotensin IIinduced thirst and sodium appetite in rat are blocked by the AT1 receptor antagonist, losartan (Dup753), but not by the AT2 antagonist, CGP 42112A. Exp Physiol 77:761-764. Medline

Bisley JW, Rees SM, McKinley MJ, Hards DK, Oldfield BJ (1996) Identification of osmoresponsive neurons in the forebrain of the rat: A fos study at the ultrastructural level. Brain Res 720:25-34. CrossRef Medline

Bisset GW, Clark BJ, Errington ML (1971) The hypothalamic neurosecretory pathways for the release of oxytocin and vasopressin in the cat. J Physiol 217:111-131. Medline

Blackburn RE, Demko AD, Hoffman GE, Stricker EM, Verbalis JG (1992a) Central oxytocin inhibition of angiotensin-induced salt appetite in rats. Am J Physiol 263:1347-R53. Medline

Blackburn RE, Stricker EM, Verbalis JG (1992b) Central oxytocin mediates inhibition of sodium appetite by naloxone in hypovolemic rats. Neuroendocrinology 56:255-263. CrossRef Medline

Brennan AR, Dolinsky B, Vu MA, Stanley M, Yeckel MF, Arnsten AF (2008) Blockade of IP3-mediated SK channel signaling in the rat medial prefrontal cortex improves spatial working memory. Learn Mem 15:93-96. CrossRef Medline

Camacho A, Phillips MI (1981) Horseradish peroxidase study in rat of the neural connections of the organum vasculosum of the lamina terminalis. Neurosci Lett 25:201-204. CrossRef Medline

Capponi AM, Rossier MF, Vallotton MB (1988) Production of inositol trisphosphate isomers and release of intracellular calcium in cultured aortic vascular smooth muscle cells. J Cardiovasc Pharmacol 12:S92-S95. Medline

Chow SY, Sakai RR, Fluharty SJ, Flanagan-Cato LM (1997) Brain oxytocin receptor antagonism disinhibits sodium appetite in preweanling rats. Regul Pept 68:119-124. CrossRef Medline

Ciura S, Bourque CW (2006) Transient receptor potential vanilloid 1 is required for intrinsic osmoreception in organum vasculosum lamina terminalis neurons and for normal thirst responses to systemic hyperosmolality. J Neurosci 26:9069-9075. CrossRef Medline

Clark AJ, Balla T, Jones MR, Catt KJ (1992) Stimulation of early gene expression by angiotensin II in bovine adrenal glomerulosa cells: roles of calcium and protein kinase C. Mol Endocrinol 6:1889-1898. CrossRef Medline

Daniels D, Yee DK, Faulconbridge LF, Fluharty SJ (2005) Divergent behavioral roles of angiotensin receptor intracellular signaling cascades. Endocrinology 146:5552-5560. CrossRef Medline

Daniels D, Mietlicki EG, Nowak EL, Fluharty SJ (2009) Angiotensin II stimulates water and $\mathrm{NaCl}$ intake through separate cell signalling pathways in rats. Exp Physiol 94:130-137. CrossRef Medline

Denton DA, McKinley MJ, Weisinger RS (1996) Hypothalamic integration of body fluid regulation. Proc Natl Acad Sci U S A 93:7397-7404. CrossRef Medline 
Enjalbert A, Sladeczek F, Guillon G, Bertrand P, Shu C, Epelbaum J, GarciaSainz A, Jard S, Lombard C, Kordon C (1986) Angiotensin II and dopamine modulate both cAMP and inositol phosphate productions in anterior pituitary cells: involvement in prolactin secretion. J Biol Chem 261:4071-4075. Medline

Epstein AN (1982) Mineralocorticoids and cerebral angiotensin may act together to produce sodium appetite. Peptides 3:493-494. CrossRef Medline

Felgendreger LA, Fluharty SJ, Yee DK, Flanagan-Cato LM (2013) Endogenous angiotensin II-induced p44/42 mitogen-activated protein kinase activation mediates sodium appetite but not thirst or neurohypophysial secretion in male rats. J Neuroendocrinol 25:97-106. CrossRef Medline

Fernandes KB, Tavares RF, Pelosi GG, Corrêa FM (2007) The paraventricular nucleus of hypothalamus mediates the pressor response to noradrenergic stimulation of the medial prefrontal cortex in unanesthetized rats. Neurosci Lett 426:101-105. CrossRef Medline

Fitts DA (1991) Effects of lesions of the ventral ventral median preoptic nucleus or subfornical organ on drinking and salt appetite after deoxycorticosterone acetate or yohimbine. Behav Neurosci 105:721-726. CrossRef Medline

Fitts DA, Tjepkes DS, Bright RO (1990) Salt appetite and lesions of the ventral part of the ventral median preoptic nucleus. Behav Neurosci 104: 818-827. CrossRef Medline

Fitts DA, Thornton SN, Ruhf AA, Zierath DK, Johnson AK, Thunhorst RL (2003) Effects of central oxytocin receptor blockade on water and saline intake, mean arterial pressure, and c-fos expression in rats. Am J Physiol Regul Integr Comp Physiol 285:R1331-R1339. CrossRef Medline

Flanagan LM, Dohanics J, Verbalis JG, Stricker EM (1992) Gastric motility and food intake in rats after lesions of hypothalamic paraventricular nucleus. Am J Physiol 263:R39-R44. Medline

Fluharty SJ, Epstein AN (1983) Sodium appetite elicited by intracerebroventricular infusion of angiotensin II in the rat: II. Synergistic interaction with systemic mineralocorticoids. Behav Neurosci 97:746-758. CrossRef Medline

Ganong WF (1977) The renin-angiotensin system and the central nervous system. Fed Proc 36:1771-1775. Medline

Ganong WF (1984) The brain renin-angiotensin system. Annu Rev Physiol 46:17-31. CrossRef Medline

Gardiner TW, Jolley JR, Vagnucci AH, Stricker EM (1986) Enhanced sodium appetite in rats with lesions centered on nucleus medianus. Behav Neurosci 100:531-535. CrossRef Medline

Geerling JC, Loewy AD (2009) Aldosterone in the brain. Am J Physiol Renal Physiol 297:F559-76. CrossRef Medline

Griffin GD, Ferri-Kolwicz SL, Reyes BA, Van Bockstaele EJ, Flanagan-Cato LM (2010) Ovarian hormone-induced reorganization of oxytocinlabeled dendrites and synapses lateral to the hypothalamic ventromedial nucleus in the female rat. J Comp Neurol 518:4531-4545. CrossRef Medline

Harada E, Yoshimura M, Yasue H, Nakagawa O, Nakagawa M, Harada M, Mizuno Y, Nakayama M, Shimasaki Y, Ito T, Nakamura S, Kuwahara K, Saito Y, Nakao K, Ogawa H (2001) Aldosterone induces angiotensinconverting-enzyme gene expression in cultured neonatal rat cardiocytes. Circulation 104:137-139. CrossRef Medline

Hebert MA, Serova LI, Sabban EL (2005) Single and repeated immobilization stress differentially trigger induction and phosphorylation of several transcription factors and mitogen-activated protein kinases in the rat locus coeruleus. J Neurochem 95:484-498. CrossRef Medline

Herbert J, Forsling ML, Howes SR, Stacey PM, Shiers HM (1992) Regional expression of $\mathrm{c}$-fos antigen in the basal forebrain following intraventricular infusions of angiotensin and its modulation by drinking either water or saline. Neuroscience 51:867-882. CrossRef Medline

Honda K, Negoro H, Dyball RE, Higuchi T, Takano S (1990) The osmoreceptor complex in the rat: evidence for interactions between the supraoptic and other diencephalic nuclei. J Physiol 431:225-241. Medline

Johnson AK, Cunningham JT, Thunhorst RL (1996) Integrative role of the lamina terminalis in the regulation of cardiovascular and body fluid homeostasis. Clin Exp Pharmacol Physiol 23:183-191. CrossRef Medline

Jomphe C, Lévesque D, Trudeau LE (2003) Calcium-dependent, D2 receptor-independent induction of $\mathrm{c}$-fos by haloperidol in dopamine neurons. Naunyn Schmiedebergs Arch Pharmacol 367:480-489. CrossRef Medline

Lemarié CA, Paradis P, Schiffrin EL (2008) New insights on signaling cas- cades induced by cross-talk between angiotensin II and aldosterone. J Mol Med (Berl) 86:673-678. CrossRef Medline

Lemarié CA, Simeone SM, Nikonova A, Ebrahimian T, Deschênes ME, Coffman TM, Paradis P, Schiffrin EL (2009) Aldosterone-induced activation of signaling pathways requires activity of angiotensin type la receptors. Circ Res 105:852-859. CrossRef Medline

Li Z, Ji G, Neugebauer V (2011) Mitochondrial reactive oxygen species are activated by mGluR5 through IP3 and activate ERK and PKA to increase excitability of amygdala neurons and pain behavior. J Neurosci 31:11141127. CrossRef Medline

Ludwig M, Sabatier N, Bull PM, Landgraf R, Dayanithi G, Leng G (2002) Intracellular calcium stores regulate activity-dependent neuropeptide release from dendrites. Nature 418:85-89. CrossRef Medline

Massi M, Epstein AN (1990) Angiotensin/aldosterone synergy governs the salt appetite of the pigeon. Appetite 14:181-192. CrossRef Medline

Mazak I, Fiebeler A, Muller DN, Park JK, Shagdarsuren E, Lindschau C, Dechend R, Viedt C, Pilz B, Haller H, Luft FC (2004) Aldosterone potentiates angiotensin II-induced signaling in vascular smooth muscle cells. Circulation 109:2792-2800. CrossRef Medline

McKinley MJ, Badoer E, Oldfield BJ (1992a) Intravenous angiotensin II induces fos-immunoreactivity in circumventricular organs of the lamina terminalis. Brain Res 594:295-300. CrossRef Medline

McKinley MJ, Bicknell RJ, Hards D, McAllen RM, Vivas L, Weisinger RS, Oldfield BJ (1992b) Efferent neural pathways of the lamina terminalis subserving osmoregulation. Prog Brain Res 91:395-402. CrossRef Medline

Miselis RR (1981) The efferent projections of the subfornical organ of the rat: a circumventricular organ within a neural network subserving water balance. Brain Res 230:1-23. CrossRef Medline

Nabika T, Velletri PA, Lovenberg W, Beaven MA (1985) Increase in cytosolic calcium and phosphoinositide metabolism induced by angiotensin II and $[\mathrm{Arg}]$ vasopressin in vascular smooth muscle cells. J Biol Chem 260: 4661-4670. Medline

Nissen R, Bourque CW, Renaud LP (1993) Membrane properties of organum vasculosum lamina terminalis neurons recorded in vitro. Am J Physiol 264:R811-R815. Medline

Oldfield BJ, Badoer E, Hards DK, McKinley MJ (1994) Fos production in retrogradely labelled neurons of the lamina terminalis following intravenous infusion of either hypertonic saline or angiotensin II. Neuroscience 60:255-262. CrossRef Medline

Paxinos G, Watson C (1986) The rat brain in stereotaxic coordinates, Ed 2. New York: Academic.

Peach MJ (1977) Renin-angiotensin system: biochemistry and mechanisms of action. Physiol Rev 57:313-370. Medline

Puryear R, Rigatto KV, Amico JA, Morris M (2001) Enhanced salt intake in oxytocin deficient mice. Exp Neurol 171:323-328. CrossRef Medline

Richard D, Bourque CW (1996) Atrial natriuretic peptide modulates synaptic transmission from osmoreceptor afferents to the supraoptic nucleus. J Neurosci 16:7526-7532. Medline

Rigatto K, Puryear R, Bernatova I, Morris M (2003) Salt appetite and the renin-angiotensin system: effect of oxytocin deficiency. Hypertension 42 : 793-797. CrossRef Medline

Roesch DM, Blackburn-Munro RE, Verbalis JG (2001) Mineralocorticoid treatment attenuates activation of oxytocinergic and vasopressinergic neurons by icv ANG II. Am J Physiol Regul Integr Comp Physiol 280: R1853-R1864. Medline

Sadoshima J, Qiu Z, Morgan JP, Izumo S (1995) Angiotensin II and other hypertrophic stimuli mediated by $\mathrm{G}$ protein-coupled receptors activate tyrosine kinase, mitogen-activated protein kinase, and 90-kD S6 kinase in cardiac myocytes. the critical role of $\mathrm{ca}(2+)$-dependent signaling. Circ Res 76:1-15. CrossRef Medline

Sakai RR, Nicolaidis S, Epstein AN (1986) Salt appetite is suppressed by interference with angiotensin II and aldosterone. Am J Physiol 251:R762R768. Medline

Sayer RJ, Hubbard JI, Sirett NE (1984) Rat organum vasculosum laminae terminalis in vitro: responses to transmitters. Am J Physiol 247:R374R379. Medline

Shade RE, Blair-West JR, Carey KD, Madden LJ, Weisinger RS, Denton DA (2002) Synergy between angiotensin and aldosterone in evoking sodium appetite in baboons. Am J Physiol Regul Integr Comp Physiol 283: R1070-R1078. CrossRef Medline 
Smith JB, Smith L, Brown ER, Barnes D, Sabir MA, Davis JS, Farese RV (1984) Angiotensin II rapidly increases phosphatidate-phosphoinositide synthesis and phosphoinositide hydrolysis and mobilizes intracellular calcium in cultured arterial muscle cells. Proc Natl Acad Sci U S A 81:78127816. CrossRef Medline

Stricker EM (1966) Extracellular fluid volume and thirst. Am J Physiol 211: 232-238. Medline

Stricker EM (1971) Effects of hypovolemia and-or caval ligation on water and $\mathrm{NaCl}$ solution drinking by rats. Physiol Behav 6:299-305. CrossRef Medline

Stricker EM, Verbalis JG (1987) Central inhibitory control of sodium appetite in rats: correlation with pituitary oxytocin secretion. Behav Neurosci 101:560-567. CrossRef Medline

Stricker EM, Verbalis JG (1996) Central inhibition of salt appetite by oxytocin in rats. Regul Pept 66:83-85. CrossRef Medline

Stricker EM, Verbalis JG (2004) Inhibition of salt appetite in rats by central oxytocin. Am J Physiol Regul Integr Comp Physiol 287:R487; author reply R487-R488. CrossRef Medline

Stricker EM, Wolf G (1966) Blood volume and tonicity in relation to sodium appetite. J Comp Physiol Psychol 62:275-279. CrossRef Medline

Suárez C, Tornadú IG, Cristina C, Vela J, Iglesias AG, Libertun C, Díaz-Torga G, Becu-Villalobos D (2002) Angiotensin and calcium signaling in the pituitary and hypothalamus. Cell Mol Neurobiol 22:315-333. CrossRef Medline

Taylor SJ, Smith JA, Exton JH (1990) Purification from bovine liver membranes of a guanine nucleotide-dependent activator of phosphoinositide- specific phospholipase C: immunologic identification as a novel G-protein alpha subunit. J Biol Chem 265:17150-17156. Medline

Templeton DM, Wang Z, Miralem T (1998) Cadmium and calciumdependent c-fos expression in mesangial cells. Toxicol Lett 95:1-8. CrossRef Medline

Toth E, Stelfox J, Kaufman S (1987) Cardiac control of salt appetite. Am J Physiol 252:R925-R929. Medline

Ullian ME, Schelling JR, Linas SL (1992) Aldosterone enhances angiotensin II receptor binding and inositol phosphate responses. Hypertension 20: 67-73. CrossRef Medline

Verbalis JG, McHale CM, Gardiner TW, Stricker EM (1986) Oxytocin and vasopressin secretion in response to stimuli producing learned taste aversions in rats. Behav Neurosci 100:466-475. CrossRef Medline

Vivas L, Chiaraviglio E, Carrer HF (1990) Rat organum vasculosum laminae terminalis in vitro: responses to changes in sodium concentration. Brain Res 519:294-300. CrossRef Medline

Wei SG, Yu Y, Zhang ZH, Felder RB (2009) Angiotensin II upregulates hypothalamic AT1 receptor expression in rats via the mitogen-activated protein kinase pathway. Am J Physiol Heart Circ Physiol 296:H1425-33. CrossRef Medline

Yoshimura R, Kiyama H, Kimura T, Araki T, Maeno H, Tanizawa O, Tohyama M (1993) Localization of oxytocin receptor messenger ribonucleic acid in the rat brain. Endocrinology 133:1239-1246. CrossRef Medline

Zhang W, Tingare A, Ng DC, Johnson HW, Schell MJ, Lord RL, Chawla S (2012) IP3-dependent intracellular $\mathrm{Ca}^{2+}$ release is required for cAMPinduced c-fos expression in hippocampal neurons. Biochem Biophys Res Commun 425:450-455. CrossRef Medline 